\section{Kochetov G., Samchenko D., Kolodko A., Kovalchuk 0., Pasko A.}

\title{
DEVELOPMENT OF TECHNOLOGY OF INDUSTRIAL WASTES TREATMENT PRODUCTS DISPOSAL BY FERRITIZATION IN THE MATRIX OF ALKALI-ACTIVATED CEMENTS
}

Об’єктом дослідження є рідкі та тверді відходи, які отримані в результаті переробки висококонцентрованих стічних вод промислових підприємств методом феритизаціі. Відомо, що гальванічні виробництва створюють великі об'єми високотоксичних відходів, які потребують подальшої переробки або безпечного захоронення. Одним з найбільш проблемних місць є застосування традиційних реагентних методів, які не забезпечують високих показників очищеної води та хімічної стійкості значної кількості твердофазних відходів водоочищення.

Використання феритизаційної технології дозволяє усунути зазначені недоліки та покращити ефективність прочесу переробки промислових стічних вод. В ході дослідження використовувалися удосконалении авторами метод феритизащї із електромагнітною активацією процесу, що дозволяє суттєво підвищити його енергоефективність. Проте щільні і стійкі осади феритизацї, які містять токсичні сполуки важких металів, потребують надійної утилізації. Але навіть при належному очищенні стічних вод від сполук важких металів, вони містять велику кількість інших забруднювачів, що унеможливлює скидання такої води у природні водойми, зокрема, через ї підвищену лужність. Розроблено екологічно безпечне використання таких некондиційних продуктів у твердому та рідкому стані як компонентів будівельних матеріалів. Найбільш ефективними цементуючими матеріалами із надійною іммобілізацію сполук промислових відходів $\epsilon$ лужні в'яжучі речовини. В роботі отримані експлуатаційні властивості таких модифікованих лужних цементів та бетонів на їх основі. Досліджено вилуговування іонів важких металів із матриці матеріалу та доведено їх надійну фіксацію у структурі лужних цементів. Завдяки цьому іммобілізація продуктів водоочищення в лужнх цементах та бетонах на їх основі не погіршує показники їх експлуатаційних властивостей і при цьому забезпечує переваги такої утилізації відходів.

У порівнянні з аналогічними відомими технологіями розроблено повністю безвідходну комплексну очистку промислових стоків гальванічних виробництв промислових підприємств.

Ключові слова: очищення промислових стоків, технологія феритизацї, феритні осади, лужний цемент, вилуговування іонів важких металів.

\section{Introduction}

The wastewater of electroplating industry today is one of the most harmful products of man-made origin. The intensive development of modern industry, in particular, electronics in the world and Ukraine, requires the use of effective technologies for the treatment of such waters in order to preserve the environment. The issue of handling such waste has not yet been resolved to a sufficient degree, which makes it possible to form environmental problems and a danger to the environment.

In order to avoid such problems, it is necessary to apply an integrated approach to the recycling of electroplating waste, not only by water treatment, but also by deeper processing of the obtained products. Therefore, research in this direction is relevant.

\section{The object of research and its technological audit}

The object of research is liquid and solid wastes resulting from the processing of highly concentrated wastewater from industrial enterprises using the ferritization method. The spent highly concentrated solutions (electrolytes, the solution after the regeneration of ion exchange filters), according to the results of a survey of electroplating industries of various industrial enterprises, make up 2-5\% [1] of the total wastewater of industrial enterprises. At the same time, the content of pollutants in them is $45 \div 75 \%$ of their total volume [2]. Wastewater from electroplating industry is characterized by a significant content of highly toxic nickel compounds, which share reaches $20 \%$ of the total content of heavy metals. The emissions of such products into the environment lead, in addition to the environmental burden, also to the loss of precious metals, which natural sources are limited.

Wastewater treatment of galvanic production at the majority of Ukrainian enterprises is carried out by traditional reagent methods [3]. However, such methods are also characterized by a number of disadvantages, including not only increased reagent costs for the treatment process, but also a low treatment degree from heavy metal ions. In addition, the volume sediment reagent of wastewater treatment is chemically unstable and poorly dehydrated, 
which significantly complicates and increases the cost of their further disposal. Therefore, the question arises of the need for deeper processing of industrial waste using more efficient technologies.

Ferritization is one of the most efficient wastewater treatment methods, which make it possible to obtain in the treatment process almost insoluble compounds of nickel and other heavy metals as a result of the treatment of their ions with an alkaline reagent and oxygen [4]. This technology provides a high degree of wastewater treatment from heavy metal compounds [5]. However, in the process of wastewater treatment, in addition to the formed ferritic sediments, liquid waste with a high content of soluble salts is also formed. The resulting solid and liquid wastes require further environmentally safe disposal.

\section{The aim and objectives of research}

The aim of research is studying the possibility of using water treatment products of industrial wastes by the ferritization method as components of environmentally safe alkaline cements. This will allow to offer waste-free technology for processing wastewater from electroplating plants.

To achieve this aim it is necessary to solve the following objectives:

1. To develop cement compositions using water treatment products as components of cement.

2. To investigate the leaching processes of heavy metal ions from the matrix of cements.

3. To assess the possibility of using the developed cements for the production of general purpose concrete.

\section{Research of existing solutions of the problem}

One of the promising ways of complex disposal of industrial wastewater treatment products is their use as composite components in the manufacture of building materials, in particular, cement and concrete based on them. However, such an application of waste electroplating waste is quite problematic due to the high alkalinity of the waste environment, which is unacceptable for the use of traditional Portland cement materials. Also, this option is impossible due to the insufficiently high immobilization rates of heavy metal ions in the matrix of traditional Portland cement [6].

The solution to these problems is possible through the use of waste water treatment as components of alkaline cements and concrete based on them:

- liquid - like cement shutter;

- solid - as a filler for alkaline cements.

These cements are developed by the scientific school of the Research Institute for binders and materials named after V. D. Glukhovsky of Kyiv National University of Construction and Architecture (KNUCA) (Ukraine) [7, 8] and have unique operational properties. In particular, they may contain up to $95 \%$ of waste and related products of the industry:

- red sludge, fuel evils [9, 10];

- domain granulated slags, etc. [11, 12]

Also, alkaline cements are characterized by the ability to fix in their structure the elements of radioactive and heavy metals not only on the physical, but also on the chemical level [13].
However, these studies concern only the possibility of using electroplating waste in its pure form and in small quantities. However, studies [14, 15] show that the matrix of alkaline cements is able to fix harmful substances in both solid and powdered states, ensuring reliable fixation of ions of heavy and radioactive metals.

Thus, the results of the literature analysis suggest that the use of a matrix of alkaline cements will ensure reliable fixation of heavy metal ions contained in wastewater treatment products.

\section{Methods of research}

Water treatment products are represented by liquid and solid wastes, which are obtained as a result of processing highly concentrated wastewater using the ferritization method. The results of chemical analysis of wastes by atomic absorption spectroscopy [16] are given in Table 1.

Table 1

The composition of the main components of the treated water by ferritization

\begin{tabular}{|c|l|c|}
\hline No. & \multicolumn{1}{|c|}{ Indicator } & Value of the indicator \\
\hline 1 & Sulfates $\left(\mathrm{SO}_{4}{ }^{2-}\right), \mathrm{mg} / \mathrm{dm}^{3}$ & 25500 \\
\hline 2 & Chlorides $\left(\mathrm{Cl}^{-}\right), \mathrm{mg} / \mathrm{dm}^{3}$ & 1186 \\
\hline \multirow{3}{*}{3} & Heavy metal ions, $\mathrm{mg} / \mathrm{dm}^{3}:$ & \\
& - iron $\left(\mathrm{Fe}^{\text {tot }}\right) ;$ & 0.10 \\
& - nickel $\left(\mathrm{Ni}^{2+}\right)$ & 0.42 \\
\hline 4 & $\mathrm{pH}$ & 10.21 \\
\hline
\end{tabular}

The sediment obtained as a result of the water treatment process is crushed to a fraction of $0.5-1 \mathrm{~mm}$. The phase composition of ferritic sludge, obtained by powder $\mathrm{X}$-ray diffraction [17], is shown in Fig. 1.

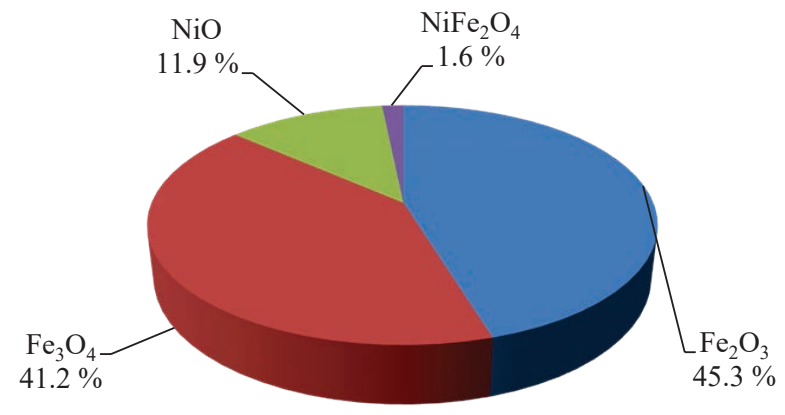

Fig. 1. Phase composition of ferritic sediment

The main calcium aluminosilicate component of alkaline cement is ground milled granulated slag produced by Ilyich Iron and Steel Works of Mariupol (Mariupol, Ukraine), ground to a specific surface of $450 \mathrm{~m}^{2} / \mathrm{kg}$ using a Blaine apparatus (Germany). Dry ash of the Ladyzhyn TPP (Ladyzhyn, Vinnytsia region, Ukraine) is also used, ground to a specific surface area of $800 \mathrm{~m}^{2} / \mathrm{kg}$ according to Blaine. Soda ash produced by JSC «Krymsoda» is used as the alkaline component. To regulate the setting time of cement, sodium lignosulfonate technical (hereinafter LST) is used according to TU 2455-028-00279580-2004.

Cement properties are determined in accordance with DSTU B.V. 2.7-181:2009 «Alkaline cement. Technical conditions» on the sample-beams of cement-sand mortar size $4 \times 4 \times 16 \mathrm{~mm}$ 
For leaching of heavy metal ions from alkaline cements, cylinders are formed with a height and diameter of $4 \times 3.5 \mathrm{~cm}$. Cement samples are distilled in distilled water at $25^{\circ} \mathrm{C}$ for 28 days in static mode.

\section{Research results}

Experimental studies are carried out using water and sludge treated with the ferritization method. The influence of the composition of the material on the properties of two types of alkaline cement: slag alkaline and alkaline composite (hybrid) is investigated. Alkaline cements are used as reference compositions, mixed with technical water. The composition of cements, their technological and operational properties are given in Table 2.

Analysis of the results shows that the introduction of alkaline cements products of industrial wastewater treatment does not significantly impair the operational properties of the material. A slight decrease in strength is observed when mixing cement with treated wastewater (for both slag alkaline and alkaline composite cement). In addition, when this water is used jointly as a shutter and ferritic sediment as filler, the material strength is stabilized at the level of the indicators of the reference compositions. In the general case, deviations of the strength of modified cements from analogs (Table 2) do not exceed 5-10\%.

In Fig. 2, 3 there are experimental data on the leaching of heavy metals from the matrix of alkaline cements obtained using industrial wastewater treatment. As the analysis of the results shows, the leaching of nickel and iron ions, first of all, depends on the technical parameters and the method of activation of the wastewater treatment process. And also on the content of ferritic sediment in the composition of the building material. The results of the leaching of nickel and iron ions from the materials shows reliable fixation of such components in the structure of the hybrid alkaline cement material. As can be seen from the obtained data, intensive leaching of heavy metal ions occurs in the first 7 days, and the process is stabilized later on.
Table 2

The composition and properties of alkaline cements using waste ferritic treatment of industrial wastewater

\begin{tabular}{|c|c|c|c|c|c|c|c|c|c|}
\hline \multirow{2}{*}{$\begin{array}{c}\text { No. of } \\
\text { compo- } \\
\text { sition }\end{array}$} & \multicolumn{5}{|c|}{ Cement composition, mass \% } & \multirow{2}{*}{$\begin{array}{l}\text { Water/ce- } \\
\text { ment ratio } \\
\text { spread }\end{array}$} & \multicolumn{3}{|c|}{$\begin{array}{l}\text { Compressive strength, } \\
\mathrm{MPa} \text {, after, days }\end{array}$} \\
\hline & Sludge & Ash & $\begin{array}{l}\text { Alkaline } \\
\text { component }\end{array}$ & Shutter & $\begin{array}{l}\text { Ferritic } \\
\text { sediment }\end{array}$ & & 3 & 7 & 28 \\
\hline 1 & 66.7 & 28.6 & \multirow{10}{*}{4.7} & technical water & - & \multirow{10}{*}{0.4} & 23.12 & 30.62 & 38.81 \\
\hline 2 & 66.7 & 28.6 & & \multirow{4}{*}{ treated water } & - & & 21.25 & 26.31 & 35.31 \\
\hline 3 & 65.0 & 27.8 & & & 2.5 & & 20.62 & 26.93 & 36.31 \\
\hline 4 & 63.3 & 27.0 & & & 5.0 & & 20.0 & 26.43 & 35.31 \\
\hline 5 & 61.5 & 26.3 & & & 7.5 & & 20.0 & 26.18 & 36.37 \\
\hline 6 & 95.3 & - & & technical water & - & & 28.12 & 35.62 & 44.06 \\
\hline 7 & 95.3 & - & & \multirow{4}{*}{ treated water } & - & & 27.50 & 21.37 & 24.06 \\
\hline 8 & 92.8 & - & & & 2.5 & & 25.62 & 31.68 & 41.25 \\
\hline 9 & 90.3 & - & & & 5.0 & & 23.75 & 29.5 & 39.31 \\
\hline 10 & 87.8 & - & & & 7.5 & & 23.12 & 32.56 & 43.18 \\
\hline
\end{tabular}

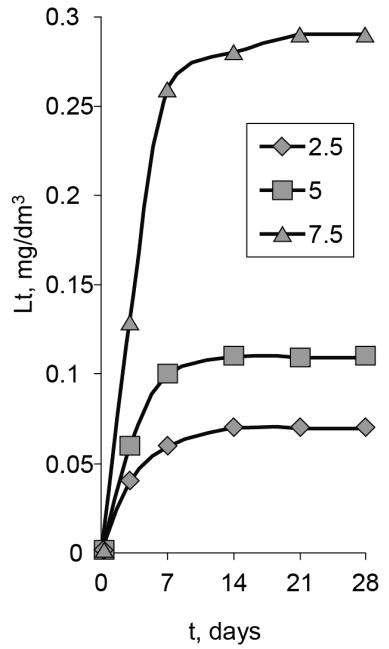

a

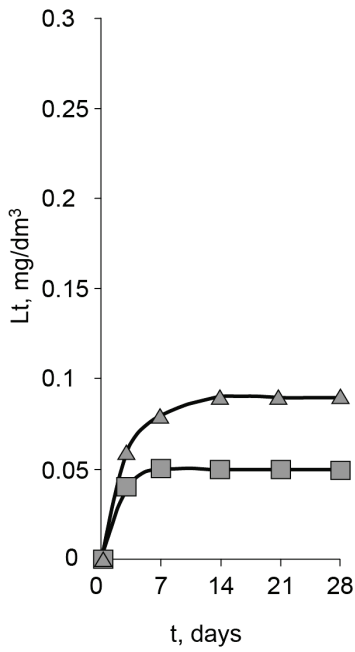

$b$

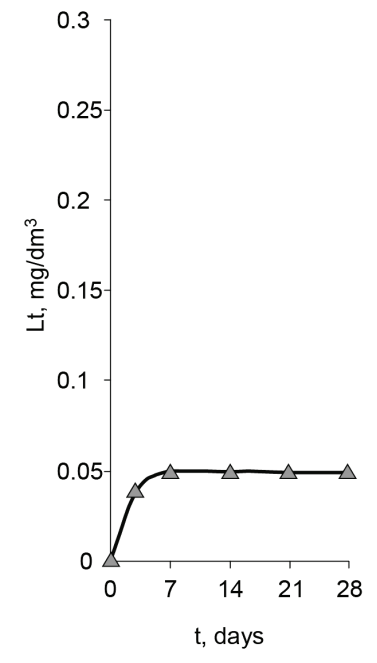

C
Fig. 2. Change of leaching indices of nickel ions from the matrix of hybrid alkaline cement depending on the activation technology of the ferritization process: a - low-temperature activation; $b$ - thermal activation; $c$ - electromagnetic pulse activation

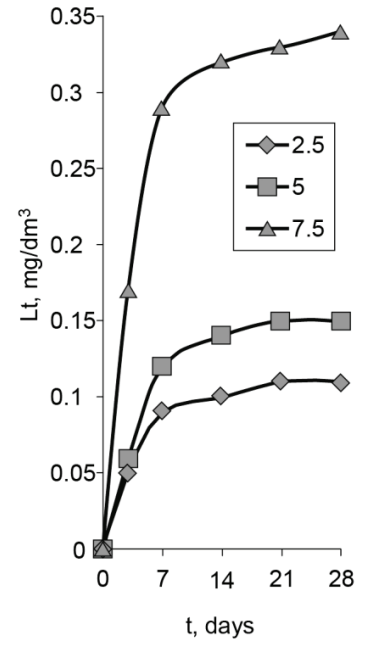

a

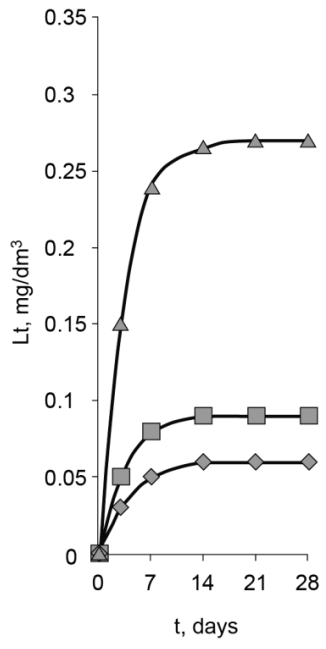

$b$

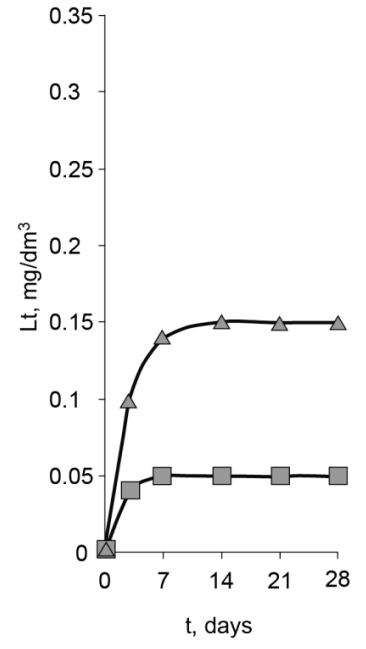

C
Fig. 3. Change in leaching indices of iron ions from the matrix of hybrid alkaline cement depending on the activation technology of the ferritization process: $a$ - low-temperature activation; $b$ - thermal activation; $c$ - electromagnetic pulse activation 
In addition, data analysis of Fig. 2, 3 indicates that for the majority of the studied compositions, the concentrations of heavy metal ions as a result of their leaching comply with the requirements of SanPiN 2.1.4.1074-01 (maximum allowable concentration (MAC) of iron is $0.3 \mathrm{mg} / \mathrm{dm}^{3}$, and for nickel it is $0.1 \mathrm{mg} / \mathrm{dm}^{3}$ ). Only in the case of a ferritization process with low-temperature activation, the concentrations of heavy metals as a result of their leaching exceed the specified requirements of the standard. For other compositions, leaching rates are within the requirements.

In addition, it should be noted that in some samples the leaching of heavy metal ions is practically absent (curves in Fig. 2, b, $c$ and Fig. 3,c). This can be explained by the fact that the residual concentrations of heavy metal ions are below the allowable measuring range of the instrument. It is noted that the leaching ability of heavy metal ions from waste water treatment is growing in the series «electromagnetic pulse activation»- «thermal activation» - «low-temperature activation». This may be due to a decrease in the amount of crystalline ferritic phases in the obtained sludge samples.

It can be noted that for alkaline cements, shuttered with water after the ferritization process and without introducing ferritic sediment into their composition, leaching of heavy metal ions is not observed. This indicates their reliable fixation in the structure of cement.

Thus, studies have shown the effectiveness of the use of alkaline cements for the localization of heavy metals from the composition of water treatment products. Therefore, the studied cements are tested for the manufacture of concrete mixtures (Table 3 ). The possibility of mixing concrete with treated water after the ferritization process is also considered.

- open the possibility of full disposal of all hazardous waste and related products of such industries.

Weaknesses. The weak points of the proposed approach include the absence of alkaline cement production in Ukraine today. This necessitates or the organization of such production to ensure the disposal process of galvanic wastes, or the import of components of such cement, in particular, ground blast furnace slag, increases the cost of the whole technology in general and the final product in particular.

Opportunities. At the same time, the proposed approach opens up the possibility of organizing a completely wastefree technology for the processing of electroplating waste. This not only solves the environmental problems of environmental protection, but also allows to receive in return the income from the sale of conditioned ferritic sediments and finished building materials or semi-finished products.

Threats. The main risk of the proposed technology is the human factor distrust of any materials made using industrial waste. It is possible to reduce such a negative factor by obtaining, as an end product, an integrated technology of concrete products operated outside residential premises - road structures, ash cans, small architectural forms, paving stones, and the like.

\section{Conclusions}

1. Compositions of alkaline cements are developed using water treatment products as a component of cement. It is established that when using liquid waste ferritic water treatment as a shutter of alkaline cements, as well as when replacing part of slag-based or hybrid cement in ferritic sediment (in the amount of $2.5-7.5 \%$ by mass), the performance of these materials does not significantly decrease (decrease compres-

Table 3

The composition of alkaline concrete with cement containing ferritic sediments

\begin{tabular}{|c|c|c|c|c|c|c|c|c|c|c|c|}
\hline \multirow{2}{*}{ No. } & \multicolumn{4}{|c|}{ Alkaline concrete $\left(\mathrm{kg} / \mathrm{m}^{3}\right)$} & \multirow{2}{*}{$\begin{array}{c}\text { Sand, } \\
\mathrm{kg}\end{array}$} & \multirow{2}{*}{$\begin{array}{c}\text { Rubble } \\
(5-20), \\
\mathrm{kg}\end{array}$} & \multirow{2}{*}{$\begin{array}{c}\text { Water }(W) / \\
\text { Treated } \\
\text { water }(E), 1\end{array}$} & \multirow{2}{*}{$\begin{array}{l}\text { Draft } \\
\text { cone, } \\
\text { cm }\end{array}$} & \multicolumn{3}{|c|}{$\begin{array}{l}\text { Compressive strength } \\
\mathrm{MPa} \text {, after, days }\end{array}$} \\
\hline & Sludge & Ash & LST & Soda & & & & & 3 & 7 & 28 \\
\hline ᄃ1 & 400 & - & 2 & 20 & 850 & 1130 & W185 & 140 & 18.29 & 28.8 & 39.1 \\
\hline С2 & 280 & 120 & 2 & 20 & 850 & 1130 & W185 & 185 & 11.01 & 30.6 & 45.7 \\
\hline C3 & 400 & - & 2 & 20 & 850 & 1130 & E185 & 100 & 20.0 & 20.8 & 43.0 \\
\hline ᄃ4 & 280 & 120 & 2 & 20 & 850 & 1130 & E185 & 165 & 13.6 & 27.2 & 41.0 \\
\hline
\end{tabular}

sive strength in the range of $5-10 \%)$. All cements obtained are M400 grade.

2. The results of leaching of heavy metal ions from the matrix of cement are investigated. The leaching results of nickel and iron ions from these materials show reliable fixation of heavy metals in the structure of alkaline cements. The leaching of nickel ions using ferritization technology with magnetic pulse activation is in the range of $0-0.5 \mathrm{mg} / \mathrm{dm}^{3}$ and iron $-0.05-1.5 \mathrm{mg} / \mathrm{dm}^{3}$, which meets the requirements for drinking water. Materials based on these cements are recommended for use in the construction of nonresidential buildings and structures

The studied concretes show a high intensity of the strength kinetics and reach $45 \mathrm{MPa}$ at the age of 28 days. Comparison of the properties of the obtained material with the base composition proves that the use of water treatment products does not affect the strength of concrete, even if a large number of such products are used.

\section{SWOT analysis of research results}

Strengths. Compared with analogues, the proposed materials and technologies:

- provide higher treatment efficiency of industrial wastes of electroplating plants;

- open up the possibility of selling part of the sediment as a commercial product;

- provide high quality of water after treatment;
3. Formulations of general purpose concrete with the use of developed cements are developed. It is shown that concretes based on alkaline cements with the use of water treatment products are characterized by high performance (39-45 MPa) even under the condition of high filling with water treatment products.
1. Dollina L. F. Sovremennaya tekhnika i tekhnologii dlya ochistki stochnykh vod ot soley tyazhelykh metallov: monograph. Dnepropetrovsk: Kontinent, 2008. 254 p.

2. Kochetov G., Zorya D., Grinenko J. Integrated treatment of rising cooper-containing wastewater // Civil and Environmental Engineering. 2010. Vol. 1, Issue 4. P. 301-305.

3. Goldmann A. Modern ferrite technology. Pittsburgh: Springer, 2006. 445 p. doi: http://doi.org/10.1007/978-0-387-29413-1 
4. Kochetov H. M., Naumenko I. V., Samchenko D. M. Ferytyzatsiina pererobka vidpratsovanykh tekhnolohichnykh rozchyniv, shcho mistiat spoluky tsynku ta nikeliu // Problemy vodopostachannia ta hidravliky. 2014. Vol. 24. P. 59-66.

5. Kochetov H. M., Samchenko D. M. Udoskonalennia ferytyzatsiinoi tekhnolohii pererobky stichnykh vod: elektromahnitna impulsna aktyvatsiia protsesu // Vodopostachannia ta vodovidvedennia. 2015. Vol. 3. P. 20-26.

6. Kryvenko P. V. Hibrydni luzhni tsementy: struktura ta vlastyvosti // Visnyk DNABA. Suchasni budivelni materialy. 2015. Vol. 1 (105). P. 59-63.

7. Kovalchuk O., Drochytka R., Krivenko P. Mix Design of Hybrid High-Volume Fly Ash Alkali Activated Cement // Advanced Materials Research. 2015. Vol. 1100. P. 36-43. doi: http://doi.org/ 10.4028/www.scientific.net/amr.1100.36

8. Special hybrid alkali activated cements for immobilization of salt concentrates of low-level radioactive wastes / Krivenko P. et. al. // Proceed. 19th Internat. Conf. «Ibausil». Weimar, 2015. P. 1-0820-1-0827.

9. Naturally Occurring Radioactive Materials in Construction: Integrating Radiation Protection in Reuse (COST Action Tu1301 NORM4BUILDING). Chapter 7 / Labrincha J. et. al. // From NORM by-products to building materials, 2017. 563 p.

10. Immobilizing properties of alkaline cementitious systems / Krivenko P. et. al. $/ / 2^{\text {nd }}$ International Symposium NON-TRADITIONAL CEMENT \& CONCRETE. Brno, 2005. P. 613-626.

11. Radioactivity and $\mathrm{Pb}$ and $\mathrm{Ni}$ immobilization in SCM-bearing alkali-activated matrices / Alonso M. M. et. al. // Construction and Building Materials. 2018. Vol. 159. P. 745-754. doi: http:// doi.org/10.1016/j.conbuildmat.2017.11.119

12. Krivenko P. Why alkaline activation -60 years of the theory and practice of alkali-activated materials // Journal of Ceramic Science and Technology. Civil Engineering Research Journal. 2017. Issue 1 (5). P. 5-16.

13. Prentice D. P. Phase evolution of slag-rich cementitious grouts for immobilisation of nuclear wastes // Advances in Cement Research. 2018. Vol. 30, Issue 8. P. 345-360. doi: http://doi.org/ 10.1680/jadcr.17.00198
14. Characterisation of a high $\mathrm{pH}$ cement backfill for the geological disposal of nuclear waste: The Nirex Reference Vault Backfill / Vasconcelos R. G. W. et. al. // Applied Geochemistry. 2018. Vol. 89. P. 180-189. doi: http://doi.org/10.1016/ j.apgeochem.2017.11.007

15. Ruiz-Santaquiteria C., Fernández-Jiménez A., Palomo A. Alternative prime materials for developing new cements: Alkaline activation of alkali aluminosilicate glasses // Ceramics International. 2016. Vol. 42, Issue 8. P. 9333-9340. doi: http://doi.org/ 10.1016/j.ceramint.2016.03.111

16. Pupyshev A. A. Atomno-absorbtsionnyy spektral'nyy analiz. Moscow: Tekhnosfera, 2009. 784 p.

17. Bokiy G. B., Poray-Koshits M. A. Rentgenostrukturnyy analiz. Vol. 1. Moscow: MGU, 1964. 490 p.

Kochetov Gennadii, Doctor of Technical Sciences, Professor, Department of Chemistry, Kyiv National University of Construction and Architecture, Ukraine, e-mail: gkochetov@gmail.com, ORCID: http://orcid.org/0000-0003-0041-7335

Samchenko Dmitry, PhD, Junior Researcher, Scientific Research Part, Kyiv National University of Construction and Architecture, Ukraine, e-mail: sama30071988@gmail.com, ORCID: http://orcid.org/ 0000-0003-3305-8180

Kolodko Anton, Postgraduate Student, Department of Chemistry, Kyiv National University of Construction and Architecture, Ukraine, e-mail: antoon11@ukr.net, ORCID: http://orcid.org/0000-0002-6791-7978

Kovalchuk Oleksandr, PhD, Senior Researcher, Scientific-Research Institute for Binders and Materials named after V. D. Glukhovsky, Kyiv National University of Construction and Architecture, Ukraine, e-mail: kovalchuk.oyu@gmail.com, ORCID: http://orcid.org/00000001-6337-0488

Pasko Anton, PhD, Scientific-Research Institute for Binders and Materials named after V. D. Glukhovsky, Kyiv National University of Construction and Architecture, Ukraine, e-mail: ua.pasko@gmail.com, ORCID: http://orcid.org/0000-0001-6455-9581 